\title{
On the Application of Multimedia in Economics Teaching
}

\author{
Mengchun Ding \& Hongxin Li \\ School of Economics and Management, Changchun University of Science and Technology \\ No.7989, Weixing Road, Changchun 130022, China \\ Tel: 86-431-8203-0456 E-mail: dingmengchun312@163.com
}

Received: April 16, 2010 Accepted: April 20, 2010 doi:10.5539/ies.v4n3p88

\begin{abstract}
Multimedia has become an important teaching technology in higher education inside and outside, with its advantages of super-media, strong expression, and interaction. The application of multimedia teaching connects closely with teaching reform and innovation. In this paper, authors conclude the defects of traditional economics teaching and the advantages of multimedia teaching, and put forward some practical measures for improving economics teaching effects by means of multimedia.
\end{abstract}

Keywords: Multimedia teaching, Economics teaching, Teaching practice

Along with the continuous expansion of computer and multimedia technology in global teaching fields, the application and popularization of computer and multimedia technology are important for improving teaching quality and efficiency, what has been proved by practices of higher education in recent years in China. The computer and multimedia technology can help to illustrate some points more vividly, quickly, and efficiently. The unique interactive function of computer and multimedia technology can optimize the class teaching in colleges and universities. It plays an important role in promoting the quality education. Economics class teaching is to make students not only know theoretical knowledge, but also use theories to explore real economic problems. To use the multimedia teaching technology and optimize the economics teaching mode can help to train students' ability of self-learning, improving the efficiency of learning.

\section{The Defects of Traditional Economics Teaching}

(1) In the traditional economics teaching mode, teacher is the source of knowledge. Students acquire knowledge by receiving information from teacher. As the receiver in teaching, students take knowledge passively. Their initiatives are not mobilized fully. The most prominent characteristic of economics is the various economic schools with their special strengths. Students should know them and use them to solve practical economic problems. In traditional class teaching, what the teacher conveys in the class are mainly from the book. Students could do nothing but receive them passively, without any room for innovation.

(2) Traditionally, the knowledge has been conveyed by literal description. Although it can also describe the objective world, the description is abstract. Learners have to imagine the objective existence by themselves based on the literal description. It is a pretty hard process. Even with the tape recorders, video recorders, slide projectors, and other electronic teaching means, due to the poor interaction, learners have to take or control the information resources to a limited degree. As a result, learners can not choose the teaching contents and process according to self conditions. Traditional economics teaching also adopts some electronic technologies. However, these traditional electronic technologies focus on the choice and design of audio-visual media, ignoring the design of learning process and teaching mode in a sense.

(3) According to the practical teaching effects of the course of economics, although the multimedia teaching method has been widely used, its positive effects, such as improving the teaching efficiency, and enhancing students' enthusiasm for learning, have not been displayed completely. Even in some cases, the application of multimedia teaching brings about a series of negative effects. For instance, the multimedia courseware are designed poorly, mostly are electronic blackboard writing or electronic notes; teachers rely on multimedia courseware too much, losing the opportunity of showing the attractiveness and the manners by means of class teaching, making the class teaching more boring. As for how to solve these problems, scholars do not present any systematic solution.

\section{Advantages of Applying Multimedia to Economics Teaching}

(1) Display the deduction process and the model clearly. Multimedia can help to change the complex mathematical derivation and model to vivid multimedia presentation, saving the teacher's blackboard time and deepening students' 
understanding. Take "Western Economics" for example. Mathematical derivation and model description are the essential contents, such as margin analysis, using geometry figures and curves to vividly reflect the relationship between economic variables and the trend of quantitative change. So do the general equilibrium theory, welfare function, and Pareto Optimality. For these contents, traditional teaching has to spend lots of time in writing formulas, drawing figures and tables, and copying cases. Besides, it is difficult for the traditional teaching reflecting the changing process of curves in one figure.

Therefore, in order to improve the teaching effect of western economics, multimedia is an inevitable choice, because it can display amounts of mathematical formulas derivations and tables and changes on the screen clearly, saving the class time, and helping students' learning. By means of the visual and impressive teaching, students can understand the knowledge deeply.

(2) Multimedia reflects characteristics of case teaching, helping to improve the ability of students. The course of economics emphasizes on both practice and theory. Without the support from practices, the theory will be water without sources, tree without roots. So, to explain the principles of economics, the teacher needs to mobilize a large number of cases in teaching. The case teaching turns into an effective way. Multimedia is the best for case teaching. Using multimedia in western economics teaching can display the wonderful cases from practices in a dynamic and vivid way. The simulation function of multimedia can help students further understand the difficulties in class. Then, the initiative of students can be mobilized and the talents can be fully displayed. By this way, it can train and develop students' ability of innovation.

(3) Multimedia net teaching is more flexible and optional, which is helpful for personalized teaching, making the teaching activities respect students' personal differences, and apply proper teaching methods to every student. Learners can arrange the study according to personal conditions. They can look for relevant knowledge conveniently, what may help to improve the learning efficiency greatly. The multimedia net teaching includes lots of media, covers a large number of information, and serves more students. Then, the multimedia materials can be shared completely, which expands the teaching space, making the teaching get rid of constrains from schools, textbooks, and teachers, and giving students more freedom in learning.

(4) Multimedia net teaching can help to form an interactive study atmosphere. The multimedia net system has a strong function of human-computer interaction, which can ensure convenient information exchanges between teachers and students. The teacher can arrange some study tasks or questions for students by the net interface, and students study under the supervision of the teacher. The teacher can monitor students' study by net space, offering instruction at any time, and helping students to focus on the subject. In this teaching mode, students can communicate with each other directly. They can exchange information by net spaces, issue personal views, analyze and judge others' ideas. Learners can achieve an agreement by means of discussion. In this teaching process, the relationship between the teacher and students changes delicately. In students' eyes, the teacher is not the director any more, but a participator in the learning process. Students are not afraid of the teacher and mobilize their initiatives fully. In the process of communicating with the teacher and other students, the student completely displays the innovation and the personality.

\section{Measures for Promoting the Teaching Reform and Enhancing the Effects of Economics Teaching}

(1) In class teaching, make and use multimedia courseware properly according to teaching contents. In teaching, it is not necessary for every class and subject using the multimedia. The use of multimedia is based on the contents of teaching and should serve the subject properly. Otherwise, it may betray the original intention and distract the students. So, the teacher must identify the important points and unimportant ones and design courseware for the important points. For the sake of students' easy learning, the contents of courseware should be precise, in case of being the electronic copy of textbook. In teaching western economics, the contents can be divided into four parts: literal description of basic economic theories, derivation of mathematical formula, changes of figures and tables, and case studies. Therefore, as making the multimedia courseware, the teacher should confirm that the courseware is for class teaching, summarizing the teaching contents into several key points, displaying them in the courseware in simple words, and highlighting the keys. By this way, students can master the center of teaching quickly and precisely.

(2) Combine the multimedia technology and the traditional teaching. We should integrate modern multimedia technology and traditional teaching together because the multimedia is not good at everything. It has advantages and also defects. It just combines the advantages of other media, but fails to achieve the best expression of other media, such as the high definition of slides and the movable images and dynamic expression of TV. Therefore, the teacher should design and use the multimedia and other media reasonably in teaching, ensuring the best integrated effect by combining them together. In the use of multimedia teaching, the traditional teaching methods should not be 
neglected. In the multimedia teaching, because the courseware is prepared in advance, the play order and schedule are fixed. As a result, the teaching contents may be inflexible and the teaching process may be routine. The teacher may fail to adjust the teaching contents in time according to students' feedback and class atmosphere. The teaching will be boring and inflexible, with poor class effects. Meanwhile, since students focus more on the screen and sound, sooner or later, they would ignore the teacher's vivid body language, visual blackboard writing, and expression changes, what may bring about positive teaching effects.

(3) In teaching practice, the teacher should notice the utility and popularity of multimedia. The multimedia has its unique functions, and also limits. In using multimedia, we must consider its utility. First of all, we should choose the proper teaching methods according to teaching contents. The principles of making a choice: the first is to cooperate with teaching, and the second is to achieve the best effect. Secondly, pay attention to the choice of multimedia materials. The aim of using multimedia is to help teaching and improve teaching effect. So, the contents conveyed by the multimedia should be deeper. In other words, what the multimedia helps to illustrate are important views, data, histories, and real materials, instead of common facts. The presentation of these materials can make people think and give them inspiration.

(4) Plan the use of multimedia and school net resources in teaching. We should combine the use of multimedia and school net resources. In economics teaching, the multimedia courseware is not only for class teaching, but also right for network learning. For one course, the class time is limited. Therefore, some multimedia courseware with contents that are not for class teaching can be put on the school website, which can not only enlarge the covering scope of economics teaching, but also improve students' initiatives of self learning, and also help to promote the improvement of students' all-round abilities.

\section{Reference}

Li, Jingzheng, \& Shang, Hongyan. (2006). Course building based on multimedia teaching as the core. Heilongjiang Education (Higher Educational Research and Appraisal), No. 3.

Liu, Hui. (2008). The application of multimedia teaching in colleges and universities ------ a case study of "Western Economics". New West, No. 3.

Wang, Jin. (2007). Multimedia teaching discussion of the computer. High Education Forum, No.1. 